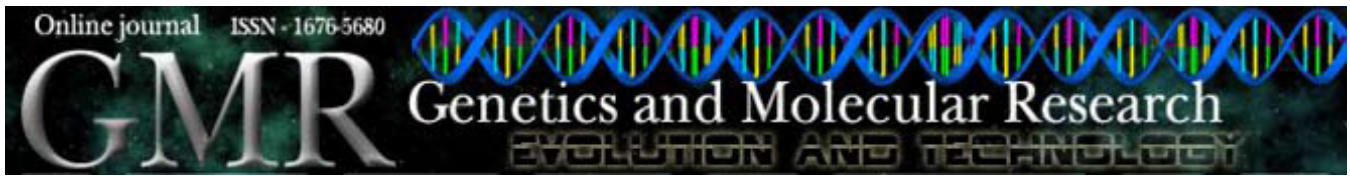

\title{
A/G GIn20Arg (exon 1) and G/A Val156Met (exon 5) polymorphisms of the human orosomucoid 1 gene in Mexico
}

\author{
L. García-Ortiz ${ }^{1,2}$, G. Vargas-Alarcón ${ }^{3}$, J.M. Fragoso ${ }^{3}$, J. Granados $^{4}$, \\ L. Maldonado Noriega ${ }^{1}$, A. Navas Pérez ${ }^{1}$, E. Huerta Reyes ${ }^{1}$, \\ J.C. Zenteno-Ruiz ${ }^{5}$ and E. Martínez-Cordero ${ }^{1}$ \\ ${ }^{1}$ Research Unit, Instituto Nacional de Enfermedades Respiratorias, \\ Mexico City, Mexico \\ ${ }^{2}$ Laboratory of Genomic Medicine and Clinic Genetics, \\ Centro Médico Nacional 20 de Noviembre, ISSSTE, \\ Mexico City, Mexico (New address) \\ ${ }^{3}$ Department of Physiology, Instituto Nacional de Cardiología Ignacio Chávez, \\ Mexico City, Mexico \\ ${ }^{4}$ Department of Immunology and Rheumatology, \\ Instituto Nacional de Ciencias Médicas y Nutrición Salvador Zubirán, \\ Mexico City, Mexico \\ ${ }^{5}$ Research Unit, Instituto de Oftalmología Fundación Conde de Valenciana, \\ Mexico City, Mexico \\ Corresponding author: E. Martínez-Cordero \\ E-mail: emartinezcordero@hotmail.com/emartinezcordero@yahoo.com.mx/ \\ garortiz@yahoo.com
}

Genet. Mol. Res. 7 (1): 7-15 (2008)

Received October 25, 2007

Accepted December 15, 2007

Published January 8, 2008

ABSTRACT. The human orosomucoid 1 gene (ORM1) codes an alpha-1-acid glycoprotein that has been classified as an acute-phase reactive protein, and a major drug-binding serum component, as well as an immunomodulatory protein with genetic polymorphisms. Evaluation of ORM variation through isoelectric focusing and immunobloting has revealed a world-wide distribution of the ORM1 F and ORM1 S alleles. We evaluated and examined the genetic characteristics of two Mexican populations that have different anthropo- 
logical and cultural antecedents, examining two ORM1 genotypes (exon 1 - A/G (Gln20Arg) and exon $5 \mathrm{G} / \mathrm{A}$ (Val156Met)) in 145 individuals, using nested polymerase chain reaction, sequencing, and restrited fragment length polymorphism. Mexican Mestizos had higher frequencies of the exon $1 \mathrm{~A}$ allele $(\mathrm{P}=0.020)$ and AA genotype $(\mathrm{P}=0.018)$ and lower frequency of the $\mathrm{G}$ allele $(\mathrm{P}=0.020)$ when compared to Teenek Amerindians. When we examined exon 5 G/A (Val156Met) polymorphisms, we found significantly higher frequencies of the $\mathrm{G}$ allele $(\mathrm{P}=0.0007)$ and the $\mathrm{GG}$ genotype $(\mathrm{P}=$ 0.0003 ) in the Mexican Mestizo population. The Teenek population had a significantly higher frequency of the A allele than has been reported for Chinese and African $(\mathrm{P}<0.05)$ populations, and the G/A genotype was more frequently found in this Mexican population than in Chinese, African and European populations $(\mathrm{P}<0.05)$.

Key words: Orosomucoid; Polymorphisms; Teenek Amerindians; Mexican populations; Allele specific polymerase chain reaction; Sequencing

\section{INTRODUCTION}

Orosomucoid (ORM) or alpha-1-acid glycoprotein is a member of the lipocalins, a family that shares at least two structurally conserved sequence motifs (Flower, 1996). It has been classified as acute-phase reactive and a major drug-binding serum component (Kremer et al., 1988; Flower, 1996; Akerstrom et al., 2000; Hochepied et al., 2003) as well as an immunomodulatory protein with the ability to down regulate complement activation, along with various phagocytic functions and T-cell-mediated activities (Hochepied et al., 2003).

ORM is synthesized predominantly in the liver as a single polypeptide of $41-43 \mathrm{kDa}$, constituted of 183 amino acids, with a hydrophobic prosthetic group, and a high content of sialic acid (Kremer et al., 1988; Yuasa et al., 1997). Although extrahepatic production of this glycoprotein has also been described, its biological significance is still obscure (Gahmberg and Andersson, 1978; Sörensson et al., 1999; Fournier et al., 1999, 2000).

Since the description of several ORM alleles by protein electrophoresis (Tokita and Schmid, 1963), various genetic polymorphisms have been reported (Kremer et al., 1988; Kopecky Jr. et al., 2003). Analysis of the two functional closely linked loci, ORM1 and ORM2, located on chromosome 9q31-32 (Dente et al., 1985, 1987; GeneID: 5004/rs2636890) disclosed three common ORM1 alleles: F1, F2 and S.

The nucleotide positions 1721 in exon 1, amino acid 20 (Gln20Arg), along with nucleotide position 3615 in exon 5, amino acid 156 (Val156Met) characterize the F/S alleles, and the $\mathrm{G} \rightarrow \mathrm{A}$ transition at the site 3615 in exon 5 distinguishes the allelic forms F1 (G) and F2 (A), as well as the S1 (G) and S2 (A) alleles (Yuasa et al., 1997, 2006).

Evaluation of ORM1 differences through isoelectric focusing and immunobloting has revealed worldwide distribution of the ORM1 F and ORM1 S alleles (Weidinger et al., 1987; Nevo et al., 1996; Sebetan et al., 1997; Yuasa et al., 1997). Some population surveys have described common occurrence of ORM1 F2 in Europeans, North Africans and West

Genetics and Molecular Research 7 (1): 7-15 (2008) www.funpecrp.com.br 
Asians. In contrast, the frequency of ORM1 S is high in Europe, and low in some Asian groups (Yuasa et al., 1997; Li et al., 1999). These genetic landmarks, including the F and $\mathrm{S}$ phenotypes, differ among ethnic groups, including native populations in Asia, Africa, Europe, and America (Johnson et al., 1969; Fan et al., 1993).

There are also reports indicating that ORM1 polymorphisms are clinically significant. An association between ORM1 F and ORM1 S with several neoplastic disorders, including breast and lung cancer, and immunologically mediated diseases, such as sarcoidosis, has been reported (Fan et al., 1995a,b; Duche et al., 2000). In addition, the bioavailability of basic or neutral drugs, and the serum concentration of hydrophophic molecules, such as some lipids and steroids, appear to be affected by specific ORM1 alleles (Kremer et al., 1988).

We examined ORM1 polymorphisms in two Mexican populations that differ in their anthropological and cultural antecedents: Mestizos and Teenek Amerindians. We also compared the allele and genotype frequencies of these Mexican groups with data from other regions of the world.

\section{MATERIAL AND METHODS}

\section{Study groups}

The study included 145 healthy, unrelated-Mexican individuals, which were divided into two groups: a group of 101 individuals classified as Mestizos of whom three generations, including their own, had been born in Mexico (Fragoso et al., 2005), and a group of 44 linguistically unclassified individuals, Amerindian Teeneks located in the Huasteca region of San Luis Potosí State (data obtained from the Instituto Nacional Indigenista, Mexico).

The Research Ethics Committee of our Institute approved the study protocol, and all individuals gave written informed consent.

\section{DNA purification}

Venous blood was collected from each participant into 7-mL EDTA Vacutainer tubes. DNA was isolated using a standard salting out procedure (Miller et al., 1988).

\section{Polymerase chain reaction and sequencing}

Nested polymerase chain reaction (PCR) was performed using 100 ng DNA. The following primers and conditions were used to amplify initially DNA fragments of $\approx 1785$ bp containing exon 1,2 and 3: 10 pmol of each of the forward and reverse primers 5'ACGTGCCTCCTGGTCTCA3' and 5'CACGTCAAAAGCAAGCATGT3' (Yuasa et al., 1997), $200 \mu \mathrm{M}$ dNTP, $2 \mathrm{mM} \mathrm{MgCl}_{2}$ and $1 \mathrm{U}$ Taq polymerase (Invitrogen, USA) in a total volume of $50 \mu \mathrm{L}$. The PCR was performed, using an initial denaturation at $94^{\circ} \mathrm{C}$ for $4 \mathrm{~min}$, followed by 30 cycles of $1 \mathrm{~min}$ at $94^{\circ} \mathrm{C}, 1 \mathrm{~min}$ at $56^{\circ} \mathrm{C}, 1 \mathrm{~min}$ at $72^{\circ} \mathrm{C}$ and a final extension of $5 \mathrm{~min}$ at $72^{\circ} \mathrm{C}$. An aliquot of the DNA product obtained through this initial PCR amplification was used as a template for the next PCR assay, using the same 
forward primer and a specific reverse primer (5'CAGAGAAGGGAGGCAGCT3'), with an annealing temperature of $55^{\circ} \mathrm{C}$ through 30 cycles. The resulting amplicon which included exon 1 yielded an expected product of $190 \mathrm{bp}$. The A/G polymorphism (Gln20Arg) of exon 1 was defined using the DNA product obtained after nested PCR. It was purified from the agarose gel and sequenced automatically (Sanger, 2001), using on BigDye Terminator cycle reactions (ABI Prism 3100 DNA Analyser) (Applied Biosystems, Foster City, CA, USA).

\section{Polymerase chain reaction and restricted fragment length polymorphism}

To detect the polymorphism G/A (Val156Met), exons 4 and 5 were amplified using a standard PCR mixture with previously reported forward and reverse primers (5'AGTGCATCTATAACACCACC3' and 5'GGTTTCACAGGGACTTCTC3') (Yuasa et al., 1997), and an annealing temperature of $54^{\circ} \mathrm{C}$ in the PCR program. The resulting DNA product of $\approx 1370 \mathrm{bp}$ was then used as a template for the next PCR, using forward and reverse primers specific for exon 5, 5'CACCATGTCCCCAGTCAGTC3' and 5'TTTCCTGCTCTGGGCCTCTG3'. The PCR program included an initial denaturation at $94^{\circ} \mathrm{C}$ for $4 \mathrm{~min}, 30$ cycles of $1 \mathrm{~min}$ at $94^{\circ} \mathrm{C}, 1 \mathrm{~min}$ at $66^{\circ} \mathrm{C}, 1 \mathrm{~min}$ at $72^{\circ} \mathrm{C}$, and a final extension of $5 \mathrm{~min}$ at $72^{\circ} \mathrm{C}$. The amplification of the 219-bp specific fragment was followed by restriction enzyme digestion with NlaIII. Based on the DNA fragments expected with this restriction enzyme, the ORM1 genotypes of exon 5 were classified as: wild homozygous (GG), yielding fragments of 174,38 and $7 \mathrm{bp}$, heterozygous (GA), showing a pattern of 174-, 117-, 57-, 38-, 7-bp products, and mutant homozygous (AA), with four fragments of $117,57,38$ and $7 \mathrm{bp}$.

\section{Statistical analysis}

Allele and genotype frequencies of the ORM1 gene polymorphisms were obtained by direct counting. Hardy-Weinberg equilibrium was evaluated with the chi-square test. The allele frequencies obtained in the two Mexican populations were compared and also with reports for other populations, using a Mantel-Haenszel chi-square test.

\section{RESULTS}

\section{Polymorphisms}

Allele and genotype frequencies of ORM1 gene polymorphisms at exon $1 \mathrm{~A} / \mathrm{G}$ (Gln20Arg) and exon $5 \mathrm{G} / \mathrm{A}$ (Val156Met) in the two Mexican populations, Mestizos and Teeneks, are shown in Table 1. The observed and expected frequencies in both polymorphic sites of ORM1 were in Hardy-Weinberg equilibrium. Mexican Mestizos had higher frequencies of exon 1 A allele $(P=0.020)$, and AA genotype $(P=0.018)$, and a lower frequency of the $\mathrm{G}$ allele $(\mathrm{P}=0.020)$ in comparison with Teenek Amerindians. Exon $5 \mathrm{G} / \mathrm{A}$ (Val156Met) polymorphism analysis in Mexican Mestizos and Teeneks revealed significantly higher frequencies of the $\mathrm{G}$ allele $(\mathrm{P}=0.0007)$ and of the $\mathrm{GG}$ genotype $(\mathrm{P}=0.0003)$ in the Mestizos, whereas the A allele and the GA genotype were significantly less frequent in Mestizos than in Teenek Amerindians ( $\mathrm{P}=0.0007$ and $\mathrm{P}=0.0003$, respectively).

Genetics and Molecular Research 7 (1): 7-15 (2008) www.funpecrp.com.br 


\begin{tabular}{|c|c|c|c|c|c|}
\hline & $\begin{array}{l}\text { Mexican Mestizos } \\
\quad(\mathrm{N}=101)\end{array}$ & & $\begin{array}{l}\text { Mexican Teeneks } \\
\quad(\mathrm{N}=44)\end{array}$ & & $\begin{array}{c}P \\
\text { value }\end{array}$ \\
\hline \multicolumn{6}{|c|}{$\mathrm{A} / \mathrm{G}$ Gln20Arg } \\
\hline Allele & $\mathrm{n}$ & af & $\mathrm{n}$ & af & \\
\hline A & 128 & 0.634 & 43 & 0.489 & 0.020 \\
\hline G & 74 & 0.366 & 45 & 0.511 & 0.020 \\
\hline Genotype & $\mathrm{n}$ & gf & $\mathrm{n}$ & gf & \\
\hline AA & 41 & 0.406 & 9 & 0.205 & 0.018 \\
\hline $\mathrm{AG}$ & 46 & 0.455 & 25 & 0.568 & NS \\
\hline GG & 14 & 0.139 & 10 & 0.227 & NS \\
\hline \multicolumn{6}{|c|}{ G/A Val156Met } \\
\hline Allele & $\mathrm{n}$ & af & $\mathrm{n}$ & af & \\
\hline G & 192 & 0.951 & 73 & 0.830 & 0.0007 \\
\hline A & 10 & 0.049 & 15 & 0.170 & 0.0007 \\
\hline Genotype & $\mathrm{n}$ & gf & $\mathrm{n}$ & gf & \\
\hline GG & 91 & 0.901 & 29 & 0.660 & 0.0003 \\
\hline GA & 10 & 0.099 & 15 & 0.340 & 0.0003 \\
\hline AA & 0 & 0.000 & 0 & 0.000 & NS \\
\hline
\end{tabular}

All populations were in Hardy-Weinberg equilibrium. NS = not significant.

Interestingly, during the analysis of ORM1 polymorphisms using nested PCR and sequencing methods there was at least one Mexican Mestizo who was heterozygous (A/T) at nt 1711 in exon 1 (Figure 1) with an amino acid change from threonine to serine (T17S), whereas no similar mutations were found in Teenek Amerindians.

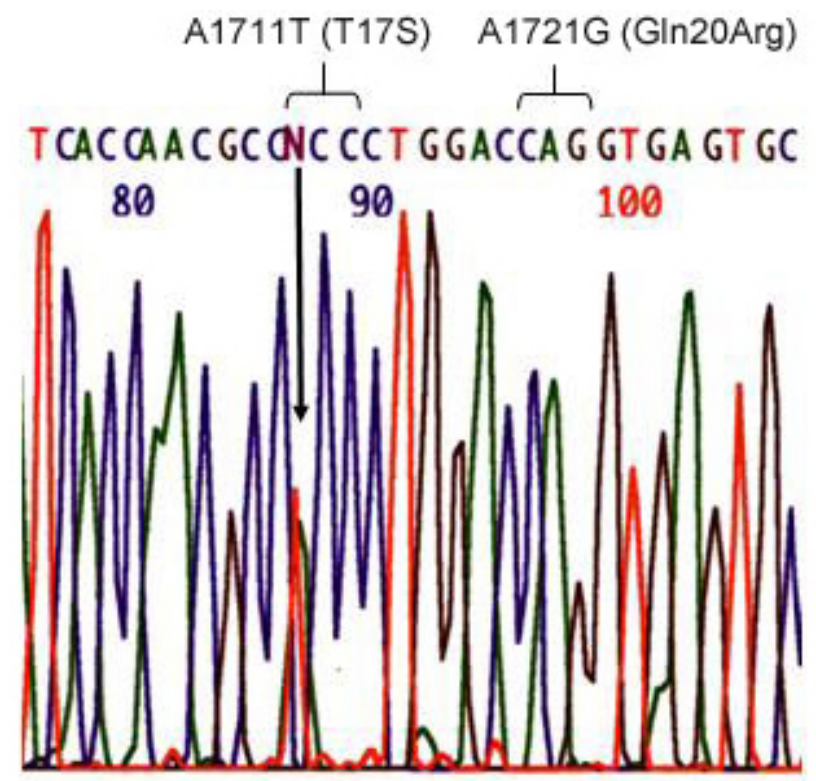

Figure 1. Nucleotide sequence of exon 1 of human orosomucoid 1 (ORM1) gene in a Mexican Mestizo. A specific heterozygous mutation (arrow) at nt 1711 characterized by the presence of adenine (green peak) and timine (red peak) is shown. The $\mathrm{A} / \mathrm{G}$ polymorphism at $\mathrm{nt} 1721$ is also shown for comparison. 


\section{Polymorphisms in Mexico compared to other world populations}

The allele frequency of the exon 5 G/A (Val156Met) polymorphism in the two Mexican populations, Mestizos and Amerindians, was compared with data from reports for other populations (Table 2). Mexican Mestizos showed similar allele and genotype frequencies for ORM1 polymorphism as those reported in Chinese, African and European populations (GeneID: 5004/rs2636890). In contrast, Teenek Amerindians had different allele frequencies. This Amerindian group had a greater frequency of A allele when compared with Chinese and African $(\mathrm{P}<0.05)$ populations, and it had a high frequency of $\mathrm{G} / \mathrm{A}$ genotype in contrast with Chinese, African and European populations $(\mathrm{P}<0.05)$. A decreased frequency of GG genotype was observed in Teeneks when they were compared with Chinese, African and European populations $(\mathrm{P}<0.05)$.

\begin{tabular}{|c|c|c|c|c|c|}
\hline & $\begin{array}{l}\text { Mexican Mestizos } \\
\quad(\mathrm{N}=101)\end{array}$ & $\begin{array}{l}\text { Mexican Teeneks } \\
\quad(\mathrm{N}=44)\end{array}$ & $\begin{array}{l}\text { Chinese } \\
(\mathrm{N}=24)\end{array}$ & $\begin{array}{l}\text { African } \\
(\mathrm{N}=23)\end{array}$ & $\begin{array}{r}\text { European } \\
(\mathrm{N}=24)\end{array}$ \\
\hline \multicolumn{6}{|l|}{ Allele } \\
\hline G (Val) & 0.951 & 0.833 & 1.000 & 0.957 & 0.938 \\
\hline A (Met) & 0.049 & $0.167^{\mathrm{a}}$ & 0.000 & 0.043 & 0.062 \\
\hline \multicolumn{6}{|l|}{ Genotype } \\
\hline $\mathrm{GG}(\mathrm{Val} / \mathrm{Val})$ & 0.901 & $0.660^{c}$ & 1.000 & 0.913 & 0.917 \\
\hline GA (Val/Met) & 0.099 & $0.340^{\mathrm{b}}$ & 0.000 & 0.087 & 0.042 \\
\hline AA (Met/Met) & 0.000 & 0.000 & 0.000 & 0.000 & 0.042 \\
\hline
\end{tabular}

Data are reported as frequency of G/A (Val156Met) exon 5 polymorphism.

ancreased frequency when compared to Chinese and African populations $(\mathrm{P}<0.05)$.

${ }^{\mathrm{b}}$ Increased frequency when compared to Chinese, African and European populations $(\mathrm{P}<0.05)$.

${ }^{c}$ Decreased frequency when compared to Chinese, African and European populations $(\mathrm{P}<0.05)$.

\section{DISCUSSION}

We determined the allele and genotype frequencies of ORM1 polymorphism through specific nested PCR, restricted fragment length polymorphism, and sequencing methods. Although the variants of this glycoprotein have been previously defined using electrophoretic characteristics (Weidinger et al., 1987; Nevo et al., 1996; Yuasa et al., 1997; Owczarek et al., 2002; Yuasa et al., 2006), the recent application of gene-specific PCR and sequencing methods has provided the possibility to distinguish the genetic heterogeneity of ORM1.

Since the nucleotide transitions that define the main alleles of ORM1 were identified at specific nucleotide positions in exons 1 and 5 , it is now possible to characterize ORM1 polymorphisms, overcoming the difficulties with differentiating similar electrophoretic patterns, in particular those produced by the F1 and F2 alleles (Nevo et al., 1996; Yuasa et al., 1997).

The distribution of the ORM1 polymorphisms in Mestizos and Teenek Amerindians showed that these Mexican populations differ not only in their anthropological and cultural antecedents, but in their genetic characteristics as well (Fragoso et al., 2005; Gamboa et al., 2006). This observation was obtained studying specifically the alleles at the ORM1 locus, ORM1 F1, ORM1 F2 and ORM1 S (Yuasa et al., 1997) that have been helpful to distinguish several world populations, and some groups with different ethnical antecedents (Yuasa et al., 2006). Mexican 
Mestizos and Amerindians were found to have different frequencies of $\mathrm{A} / \mathrm{G} \mathrm{Gln} 20 \mathrm{Arg}$ (exon 1) and G/A Val156Met (exon 5) ORM1 polymorphisms. Although it is difficult to propose a definitive cause for these genetic differences, several factors may explain this setting. A possible geographic barrier is that the Teeneks have inhabited a region known as Huasteca San Luis Potosí located in the North-Western part of Mexico subsisting as a pure native group since at least $600 \mathrm{BC}$ (Avila et al., 1995). Additionally, these Teenek Amerindians, who have been called Huastecos for more than 500 years, first by the Aztecs and later by the Spaniards, have maintained their own cultural and organizational characteristics, with minimal migration (Avila et al., 1995).

There are only few reports on ORM polymorphisms in American populations, or studies which have included native or Amerindian groups (Johnson et al., 1969), and none of them have compared their allele and genotype results with previous publications. Interestingly, our Mexican Mestizos had ORM1 features similar to other world populations, and the Teenek group revealed several differences.

Teenek Amerindians showed higher frequencies of the A allele and GA genotype of exon 5 in comparison with several Asiatic, African and European populations, considering recent published reports (GeneID: 5004/rs2636890). Although this $\mathrm{G} \rightarrow \mathrm{A}$ transition of the exon 5 is described as a Caucasoid polymorphism, and has predominantly been described in Europeans (Yuasa et al., 1997), the present study supports that it may be also common in Amerindians. In addition, the $\mathrm{G}$ allele that was frequent in Teenek Amerindians has been rarely found in some native groups in Europe (Moral et al., 1996).

In this report, we analyzed the three major alleles of the ORM1 locus, nevertheless the ORM1 polymorphisms appear to be more complex than previously thought, in particular since the structure and diversity of the ORM1 and ORM2 genes have been explored. Although the rearrangement of the ORM1 and ORM2 genes was not specifically evaluated in our population, because it was not the main objective of this study, several interesting results have been recently described. The frequencies of duplicated or triplicate genes encoding ORM1 and ORM2 proteins, together with the appearance of different gene arrangements, may distinguish some populations, in terms of their ORM diversity (Nakamura et al., 2000; Owczarek et al., 2002; Yuasa et al., 2006). For example, the duplication of ORM1 gene is frequent in Africans and Japanese (high as 10-20\%) (Nakamura et al., 2000; Yuasa et al., 2006), and other studies dealing with European and Australian populations suggest that the increase in gene numbers may occur at appreciable frequencies (Dente et al., 1987; Rocha et al., 1993; Owczarek et al., 2002).

The presence of at least two types of ORM1 F1: the ORM1 F1 (Ala) and ORM1 F1 (Thr), which depend on a $\mathrm{G} \rightarrow \mathrm{A}$ transition at nt 1708 (amino acid 16) in exon 1, has been recently described in Africans (Yuasa et al., 2006). Our study revealed that in addition to the frequent occurrence of G allele ORM1 F1 (Ala), it is possible to find other ORM1 mutations of exon 1 in Mexican Mestizos (for example: heterozygous A/T at nt 1711) which have not been previously described, and merits a further investigation.

ORM1 S has also been classified as ORM1 S2 (T) and ORM1 S2 (C) according to the presence of $\mathrm{T}$ or a $\mathrm{C}$ at nt 3626 (Yuasa et al., 2006), which is of interest because this change was observed in a Ghanaian family; a low frequency of allele S2 has been described in some Asiatic, Finns, and Swedish groups (Fan et al., 1993), and the study of Mexican subjects did not reveal the presence of this ORM1 S2 polymorphism. Therefore, further studies are needed in order to demonstrate whether these gene arrangements may distinguish other world populations or specific ethnic groups, including Amerindians.

Genetics and Molecular Research 7 (1): 7-15 (2008) www.funpecrp.com.br 
Several groups have pointed out the possible clinical significance of the mentioned ORM1 polymorphisms (Mittermüller and Weidinger, 1992; Fan et al., 1995a,b; Duche et al., 2000; Lee et al., 2001; Hashimoto et al., 2004). According to previous observations, the A/G (Gln20Arg) variants of exon 1 of ORM1 have been found to be associated with sarcoidosis (A allele), and with lung and breast cancer (G allele) (Fan et al., 1995b). Although the cause of this relation has not been elucidated, it has been suggested that some ORM1 alleles might be implicated in the immunological mechanisms that may downregulate the anti-tumoral response (Fan et al., 1995a).

In summary, the study of the ORM1 polymorphisms led us to distinguish two Mexican populations with different anthropological, cultural, as well as genetic antecedents. The possibility to compare our results with other publications has also provided the opportunity to analyze the distribution of the main ORM1 variants in different ethnic groups. We are now studying whether some alleles of ORM1 may have a possible role as genetic susceptibility factors associated with the development or progression of disease.

\section{ACKNOWLEDGMENTS}

Research supported in part by grants from the Consejo Nacional de Ciencia y Tecnología, Mexico. We thank Dr. Diana E. Aguilar León and Dr. Juan Carlos Zenteno Ruiz for helping us with the Molecular Biology methods. The authors are grateful to the study participants. Institutional Review Board approval was obtained for all sample collections.

\section{REFERENCES}

Akerstrom B, Flower DR and Salier JP (2000). Lipocalins: unity in diversity. Biochim. Biophys. Acta 1482: 1-8.

Avila A, Barthas B and Cervantes A (1995). Los huastecos de San Luis Potosí. Etnografía contemporánea de los pueblos indígenas de México Región Oriental. Instituto Nacional Indigenista, San Luis Potosí.

Dente L, Ciliberto G and Cortese R (1985). Structure of the human alpha 1-acid glycoprotein gene: sequence homology with other human acute phase protein genes. Nucleic Acids Res. 13: 3941-3952.

Dente L, Pizza MG, Metspalu A and Cortese R (1987). Structure and expression of the genes coding for human alpha 1-acid glycoprotein. EMBO J. 6: 2289-2296.

Duche JC, Urien S, Simon N, Malaurie E, et al. (2000). Expression of the genetic variants of human alpha-1-acid glycoprotein in cancer. Clin. Biochem. 33: 197-202.

Fan C, Sikström C, Beckman G and Beckman L (1993). Orosomucoid polymorphism in Finns, Swedes and Swedish Saamis. Hum. Hered. 43: 272-275.

Fan C, Stendahl U, Stjernberg N and Beckman L (1995a). Association between orosomucoid types and cancer. Oncology 52: 498-500.

Fan C, Nylander PO, Stendahl U, Thunell M, et al. (1995b). Synergistic interaction between ORM1 and C3 types in disease associations. Exp. Clin. Immunogenet. 12: 92-95.

Flower DR (1996). The lipocalin protein family: structure and function. Biochem. J. 318 (Pt 1): 1-14.

Fournier T, Bouach N, Delafosse C, Crestani B, et al. (1999). Inducible expression and regulation of the alpha 1-acid glycoprotein gene by alveolar macrophages: prostaglandin E2 and cyclic AMP act as new positive stimuli. $J$. Immunol. 163: 2883-2890.

Fournier T, Medjoubi N and Porquet D (2000). Alpha-1-acid glycoprotein. Biochim. Biophys. Acta 1482: 157-171.

Fragoso JM, Rodriguez-Perez JM, Perez-Vielma N, Martinez-Rodriguez N, et al. (2005). Beta1 adrenergic receptor polymorphisms Arg389Gly and Ser49Gly in the Amerindian and Mestizo populations of Mexico. Hum. Biol. 77: 515-520.

Gahmberg CG and Andersson LC (1978). Leukocyte surface origin of human alpha1-acid glycoprotein (orosomucoid). $J$. Exp. Med. 148: 507-521.

Gamboa R, Zamora J, Rodriguez-Perez JM, Fragoso JM, et al. (2006). Distribution of paraoxonase PON1 gene polymorphisms in Mexican populations. Its role in the lipid profile. Exp. Mol. Pathol. 80: 85-90.

Genetics and Molecular Research 7 (1): 7-15 (2008) www.funpecrp.com.br 
Hashimoto S, Asao T, Takahashi J, Yagihashi Y, et al. (2004). Alpha-acid glycoprotein fucosylation as a marker of carcinoma progression and prognosis. Cancer 101: 2825-2836.

Hochepied T, Berger FG, Baumann H and Libert C (2003). Alpha(1)-acid glycoprotein: an acute phase protein with inflammatory and immunomodulating properties. Cytokine Growth Factor Rev. 14: 25-34.

Johnson AM, Schmid K and Alper CA (1969). Inheritance of human alpha-1-acid glycoprotein (orosomucoid) variants. J. Clin. Invest. 48: 2293-2299.

Kopecky V Jr, Ettrich R, Hofbauerova K and Baumruk V (2003). Structure of human alpha1-acid glycoprotein and its high-affinity binding site. Biochem. Biophys. Res. Commun. 300: 41-46.

Kremer JM, Wilting J and Janssen LH (1988). Drug binding to human alpha-1-acid glycoprotein in health and disease. Pharmacol. Rev. 40: 1-47.

Lee SY, Lim JW and Kim YM (2001). Effect of alpha1-acid glycoprotein expressed in cancer cells on malignant characteristics. Mol. Cells 11: 341-345.

Li JH, Xu JQ, Li Y, Zhuang YY, et al. (1999). Genetic polymorphisms of orosomucoid on the Han population in Nanjing of China. Clin. Chim. Acta 288: 161-168.

Miller SA, Dykes DD and Polesky HF (1988). A simple salting out procedure for extracting DNA from human nucleated cells. Nucleic Acids Res. 16: 1215.

Mittermüller J and Weidinger S (1992). Genetic study of orosomucoid by isoelectric focusing and immunoprinting in patients with carcinoma. Electrophoresis 13: 785-786.

Moral P, Sandiumenge T, Vives S, Lutken N, et al. (1996). Human genetic variation in the Sierra de Gredos mountain (central Spain): study of several polymorphisms. Ann. Hum. Biol. 23: 213-221.

Nakamura H, Yuasa I, Umetsu K, Nakagawa M, et al. (2000). The rearrangement of the human alpha(1)-acid glycoprotein/ orosomucoid gene: evidence for tandemly triplicated genes consisting of two AGP1 and one AGP2. Biochem. Biophys. Res. Commun. 276: 779-784.

Nevo S, Picornell A, Miguel A, Castro JA, et al. (1996). Orosomucoid (ORM1) polymorphism in Arabs and Jews of Israel: more evidence for a middle eastern origin of the Jews. Hum. Biol. 68: 217-229.

Owczarek CM, Owczarek AL and Board PG (2002). Identification and characterization of polymorphisms at the HAS alpha1-acid glycoprotein (ORM*) gene locus in Caucasians. Genet. Mol. Res. 1: 96-105.

Rocha J, Amorim A, Luckenbach C, Kompf J, et al. (1993). Subtyping of alkylated human orosomucoid: evidence for a duplicated gene, ORM1*F2S. Electrophoresis 14: 235-237.

Sanger F (2001). The early days of DNA sequences. Nat. Med. 7: 267-268.

Sebetan IM, Oshida S, Yuasa I and Tie J (1997). Genetic polymorphisms of orosomucoid ORM1 and ORM2 in Egyptians, Sudanese, and Qataris: occurrence of two new alleles. Hum. Biol. 69: 121-129.

Sörensson J, Matejka GL, Ohlson M and Haraldsson B (1999). Human endothelial cells produce orosomucoid, an important component of the capillary barrier. Am. J. Physiol. 276: H530-H534.

Tokita K and Schmid K (1963). Variants of alpha-1-acid glycoprotein. Nature 200: 266.

Weidinger S, Muller T, Schwarzfischer F and Cleve H (1987). Three new orosomucoid (ORM) variants revealed by isoelectric focusing and print immunofixation. Hum. Genet. 77: 286-288.

Yuasa I, Umetsu K, Vogt U, Nakamura H, et al. (1997). Human orosomucoid polymorphism: molecular basis of the three common ORM1 alleles, ORM1*F1, ORM1*F2, and ORM1*S. Hum. Genet. 99: 393-398.

Yuasa I, Nakamura H, Umetsu K, Irizawa Y, et al. (2006). The structure and diversity of alpha1-acid glycoprotein/ orosomucoid gene in Africans. Biochem. Genet. 44: 145-160. 